\title{
Forsking på barn og ungdoms tekstar og tekstpraksisar på fritida, med eit nordisk fokus
}

\author{
Gudrun Kløve Juuhl ${ }^{1 \star}$ og Maja Michelsen ${ }^{2}$ \\ ${ }^{1}$ Høgskulen $i$ Volda $;{ }^{2}$ Høgskolen $i$ Østfold
}

\begin{abstract}
Samandrag
Denne artikkelen gjev oversikt over nordisk forsking på barn og ungdoms tekstar og tekstpraksisar på fritida dei siste tjue åra (2000-2019). I denne perioden har vilkåra for barns deltaking i ulike tekstkulturar endra seg som følgje av den teknologiske utviklinga, og artikkelen strekar dermed opp eit forholdsvis nytt forskingsfelt, der særleg barns deltaking i digitale og multimodale tekstar og tekstpraksisar vert tematisert. Føremålet med den systematiske reviewen er å finna ut kva som kjenneteiknar den nordiske forskinga på feltet teoretisk, metodisk og empirisk. Forskinga vi har funne, dreg i stor grad vekslar på sosiokulturell læringsteori og new literacy studies, og observasjon, intervju og tekstsanalysar er metodar som vert hyppig nytta. Samla sett gir den nordiske forskinga eit ganske tydeleg bilete av kva barn og unge brukar lesing og skriving til på fritida, korleis barn og unge skaffar seg teksterfaringar, kva område dei frivillige tekstpraksisane er knytte til og kven barn og unge kommuniserer med, men ny forsking bør blant anna supplera den eksisterande forskinga ved å undersøkja deltaking i tekstpraksisar på tvers av kontekstar, på tvers av medium og over lengre tid.
\end{abstract}

Nøkkelord: Forskingsoversyn; fritidstekstar; fritidstekstpraksisar; barn og ungdoms tekstpraksisar

\begin{abstract}
Research on the out-of-school texts and literary practices of children and youth, with a Nordic focus

This article gives an overview of Nordic research on children's and youth's texts and literacy practices out of school for the last twenty years (2000-2019). During this period the conditions for children's participation in various text cultures have changed as a result of technological development, and thus the article highlights a relatively new research field, where especially children and youth's participation in digital and multimodal texts and text practices is explored. The aim of this systematical review is to find out what defines the Nordic research in the field, theoretically, methodologically and empirically. The research is to a large extent rooted in socio-cultural learning theories and New Literacy Studies, and relies primarily on observation, interviews and text analyses. The research gives an overall picture of what young people in the Nordic countries use reading and writing for out of school, how they get textual experiences, what spheres of life the out of school text practices are related to and who children and youth communicate with. New research
\end{abstract}

^Korrespondanse: Gudrun Kløve Juuhl, e-post: gudrun.klove.juuhl@hivolda.no

(C) 2020 Gudrun Kløve Juuhl \& Maja Michelsen. This is an Open Access article distributed under the terms of the Creative Commons Attribution 4.0 International License (https://creativecommons.org/licenses/by-nc/4.0/), allowing third parties to copy and redistribute the material in any medium or format and to remix, transform, and build upon the material for any purpose, even commercially, provided the original work is properly cited and states its license.

Citation: G. K. fuuhl $\mathfrak{E}$ M. Michelsen. "Forsking på barn og ungdoms tekstar og tekstpraksisar på fritida, med eit nordisk fokus" Nordic fournal of Literacy Research, Special issue: Barn og unges tekstpraksiser på firtiden, 6(3), 2020, 4-26. 
can supplement the existing by exploring participation in text practices across contexts and media and for longer periods of time.

Keywords: Review; out of school texts; out of school literacy; children and youth's literacy practices

Responsible editor: Per Henning Uppstad

Received: December, 2019; Accepted: October, 2020; Published: December, 2020

\section{Innleiing}

Forsking på barn og ungdoms deltaking i ulike tekstkulturar skjer i dag i stor grad i ein skulekontekst. Forsking på tekstpraksisar i fritidssamanheng er aukande, men likevel meir spreidd og sjeldan enn tilsvarande forsking knytt til skulekonteksten (Schultz, Hull \& Higgs, 2016). Dette gjeld òg i nordisk samanheng (sjå Juuhl, 2014; Michelsen, 2016). Forsking på tekstpraksisar i fritidssamanheng kan gje oss innsikt i fleire aspekt ved literacy og læring, og dessutan korleis barn og unge er aktive deltakarar i samfunnet generelt og ulike tekstkulturar spesielt. For det fyrste kan slik forsking bidra til å fortelja oss korleis barn og ungdom uttrykkjer seg i, og handterer, tekstkulturane dei er ein del av. For det andre kan denne forskinga supplera skuleforskinga, og gje ei meir nyansert forståing av den komplekse aktiviteten det er å lesa og skriva. For det tredje kan forskinga seia noko om kva som må til for å kunna byggja bru mellom skuleliv og kvardagsliv, og mellom literacy heime og i meir formelle læringssituasjonar.

Artikkelen gjev eit forskingsoversyn over feltet med problemstillinga: Kva karakteriserer nordisk forsking om barn og ungdoms fritidstekstar og fritidstekstpraksisar? Med denne problemstillinga vil vi for det fyrste undersøkja kva som karakteriserer denne forskinga teoretisk og metodisk. For det andre vil vi undersøkja kva slags empiri som er valt, og kva for funn som er gjorde (jf. Schultz et al., 2016). Eit slikt oversyn vil bidra til å streka opp eit relativt nytt forskingsfelt i nordisk samanheng, og oversynet vil også kunna peika på kva tema og aldersgrupper som er meir og mindre utforska, og kva vi manglar kunnskap om.

Reviewen kan seiast å vera ein såkalla meta-etnografi (Prøitz, 2015). Det vil seia at vi oppsummerer og syntetiserer funn frå kvalitative studiar, særleg etnografiske og fortolkande studiar. I alt er 93 artiklar og forskingsarbeid analyserte, og desse tekstane er resultat av ein utsilingsprosess frå 877 treff. Ei utfordring ved å laga ei slik oversikt, er at dei ulike studiane kan vera forholdsvis heterogene, både metodisk og teoretisk. Eit slikt forskingsoversyn er likevel viktig for å kunna forstå forsking på eit tema, som i dette tilfellet er barn og unges tekstpraksisar på fritida, og for å kunna sjå på forholdet mellom ulike forskingstradisjonar.

\section{Utval og innleiande avgrensing av forskingsfeltet}

Ei innleiande avgrensing er at vi vil sjå på nordisk forsking frå dei siste tjue åra, altså frå 2000 og framover. Grunnen til det er at det manglar eit slikt samla og 


\section{G. K. Fuuhl \& M. Michelsen}

nyare oversyn i ein nordisk kontekst, medan Schultz med fleire (2016) delvis har gjeve eit slikt oversyn internasjonalt. Björkvall og Engblom (2007) har tidlegare bidrege med ein bakgrunnsrapport over forskingsfeltet for perioden 1987-2006, men då med fokus på svensk og internasjonal forsking. Avgrensinga til dei siste tjue åra er gjort både av praktiske omsyn og fordi det desse åra har skjedd ei utvikling i vilkåra for barn og ungdoms tekstproduksjon og forskinga på denne med utbreiinga av digitale og sosiale medium. I denne perioden har det òg skjedd ein transformasjon med tanke på at barn i større grad enn tidlegare er vortne konsumentar, noko Björkvall \& Engblom (2007, s. 94) peikar på. Utbreiinga av nye medium må difor sjåast i samanheng med kommersialisering og det at barn i dag vert betrakta som ei kjøpesterk gruppe. 2000-talet kan også sjåast som eit startpunkt for diskusjonar om det utvida tekstomgrepet, og Internett vart særleg tematisert på grunn av moglegheitene i denne teknologien med tanke på mediekonvergens, multimodalitet, interaktivitet og hypertekstualitet (sjå t.d. Karlson \& Ledin, 2002; Schwebs \& Otnes, 2006), noko som har prega tekst- og medieforskinga sidan. Dermed har det òg vore eit sentralt føremål for mykje av forskinga som gjeld barn og unges literacy å undersøkja nettopp digitale og multimodale tekstpraksisar. Trass i at svært mykje av forskinga tematiserer det digitale og multimodale, utelukkar ikkje det at det finst tekstpraksisar som er meir orienterte mot det skriftlege og papirbaserte, slik som til dømes det å lesa romanar. Vi vil difor understreka at tekst i denne artikkelen kan visa til romanar så vel som dataspel, teikneseriar og fotballkort, fordi alle desse tekstane kan vera aktuelle å tematisera i samband med frivillige tekstpraksisar.

Ei anna innleiande avgrensing er at vi reknar barn og ungdom som dei under tjue. Nokre studiar av ungdoms tekstpraksisar omfattar også eldre ungdomar og unge studentar (t.d. Hennig, 2018), men i vår samanheng vel vi å avgrensa oppover ved skulealder, og sjå på tjueåringar som vaksne. Dette har både med at å avgrensa ved skulealder gjer denne forskinga meir samanliknbar med anna forsking på barn og ungdoms tekstar og tekstpraksisar - altså den som er knytt til skulen, og med at 20-åringar på mange måtar har meir felles i livssituasjon og tekstkompetanse med andre vaksne enn med barn. Ei nedre aldersgrense set vi ikkje. «Tidleg literacy» både i barnehage og på fritida er eit etablert forskingsfelt, og vi veit at barn held på med tekstar og såleis er involverte i tekstpraksisar også før dei når skulealder, både i barnehage og fritid (sjå t.d. Fast, 2007; Gjems, 2016; Purcell-Gates, 1996; Tolchinsky, 2004).

I problemstillinga har vi nytta omgrepet tekstpraksis som er ei omsetjing av det engelske omgrepet literacy practice. Literacy practice er særleg nytta innanfor etnografisk forsking på lese- og skriveaktivitetar (jf. Barton \& Hamilton, 1998; Heath, 1982), og omgrepet viser til at det eksisterer sosialt etablerte måtar å bruka tekst på. Omgrepet kan også visa til bestemte normer, verdiar eller haldningar som ligg til grunn for eller vert forma av måtar å delta i tekstlege aktivitetar på. Ein tekstpraksis vert etablert dersom bestemte tekstlege aktivitetar, slik som eksempelvis å spela dataspel, å blogga eller å lesa ein teikneserie, gjentek seg over tid. 
Innanfor den etnografiske tradisjonen er ein gjerne oppteken av å undersøkja autentiske og frivillige lese- og skrivesituasjonar (jf. Barton \& Hamilton, 1998), og forskinga skil seg dermed frå forsking på meir institusjonelle og påtvinga skriveog leseaktivitetar, slik som lesing og skriving i opplærings- og testsamanheng. Internasjonalt har desse frivillige tekstpraksisane fått neminga out-of-school-literacy (Schultz et al., 2016). Det som kjenneteiknar såkalla out-of-school-literacy utover at den er prega av frivilligheit, er at aktivitetane ikkje nødvendigvis har læring som hovudføremål. Grensene mellom frivillige og påtvinga praksisar kan vera flytande, og vi kan finna eksempel på meir skulske tekstaktivitetar på fritida, slik som å gjera lekser eller å lesa seg opp på eit fagleg tema som ein finn personleg interessant. Omvendt kan ein òg finna eksempel på meir frivillige tekstaktivitetar i skulekonteksten, slik som til dømes å skriva av ei kakeoppskrift i friminuttet (Malmbjer, 2014).

Det er i hovudsak tre stader vi kan få forskingsbasert kunnskap om barn og unges frivillige tekstpraksisar: På skulen, i barnehagen og heime / elles på fritida. Det kan synast paradoksalt at vi kan få kunnskap om barns frivillige fritidstekstpraksisar frå forsking som skjer i skulekonteksten, men med utgangspunkt i den flytande grensa mellom frivillige og påtvinga aktivitetar som er nemnd tidlegare, vil vi argumentera for relevansen til denne forskinga. Denne forskinga kan seia noko om korleis barn dreg vekslar på teksterfaringar dei har fått på fritida i ein skulekontekst. Slike studiar kan også undersøkja sjangrar som tradisjonelt er knytte til fritida, slik som det å spela spel eller å blogga. Vidare kan denne forskinga potensielt fortelja noko om pedagogiske moglegheiter og umoglegheiter med tanke på å bringa dei frivillige tekstpraksisane inn i klasserommet.

Når det gjeld barnehagen, er han i større grad enn skulen prega av uformell læring. Barnehagen er dessutan ein stad som har likskapar med heimen på andre måtar, t.d. når det gjeld innreiing og organisering av dagen, og difor vert barnehagedidaktikk gjerne omtala som kvardagslivets didaktikk (sjå t.d. Håberg, 2016). Difor er det også vanskelegare å trekkja eit tydeleg skilje mellom frivillige og påtvinga praksisar, og fritid og ikkje-fritid, i forskinga på literacy i barnehagen. Barns tekstaktivitetar innanfor denne konteksten er ofte, men ikkje alltid, initierte av ein pedagog (sjå t.d. Hopperstad, 2013 om målestund og Åberg, 2018 om barns arbeid med digitale forteljingar i barnehagen), men aktivitetane skil seg likevel frå skulens praksisar. Skilnader er at dei gjerne vert gjennomførte i mindre grupper, at dei har eit vedteke ideal om å vera leikprega, jf. rammeplan for barnehagen (Kunnskapsdepartementet, 2017), og at dei gjerne gjev større rom for barnas initiativ, nyfikne og medverknad. Det skjer også barneinitierte literacyaktivitetar i barnehagen, som når nokre barn teiknar eller leikar skule på teiknerommmet $\mathrm{i}$ frileiktida, men dei er gjerne tilfeldig og dermed i mindre grad fanga opp av forskinga, som oftare konsentrerer seg om planlagde literacyaktivitetar. Dette er grunnar til at også tekstaktivitetar initierte av pedagogar i barnehagen kan koma innanfor ramma for dette forskingsoversynet. 


\section{G. K. Fuuhl \& M. Michelsen}

\section{Metode og materiale}

For å finna forsking på barn og unges tekstar og tekstpraksisar på fritida gjennomførte vi ein systematisk review. Med forsking meiner vi i denne samanhengen vitskaplege artiklar, artiklar i antologiar og doktorgradsavhandlingar. I hovudsøket søkte vi i norske, nordiske og internasjonale søkedatabasar for å sikra oss at søket resulterte i treff frå alle dei nordiske landa. Søkjedatabasane vi søkte i var: Eric, DiVa, Google Scholar, Idunn, Norart, NORA og SkrivBiB. Vi såg på desse som relevante fordi dei omfattar forsking frå humaniora, pedagogikk og utdanning, og i tillegg er ein av dei, SkrivBib, ein eigen database for nordisk skriveforsking. Søk i desse databasane gav til saman 877 treff.

I tillegg til den systematiske reviewen nytta vi oss av handsøk. Det innebar at vi gjekk gjennom litteraturlister i dei artiklane og avhandlingane vi fann gjennom det systematiske søket. Vidare gjekk vi gjennom dei to utgjevne antologiane frå den nordiske forskarkonferansen Skriv! Les! i perioden 2012 til 2014, og alle publiserte artiklar i Nordic Fournal of Literacy Research til og med 2019. I arbeidet med utveljinga loggførte vi alle søka våre i eit felles dokument i Google Docs.

Ein tilrådd framgangsmåte for systematisk review er å arbeida i ulike fasar, der ein startar med å danna eit review-team, for så å utvikla forskingsspørsmål, søkjeprotokoll og inklusjonskriterium, før ein til slutt kodar og analyserer materialet (Gough, Oliver \& Thomas, 2012; Prøitz, 2015). Ein slik framgangsmåte har vi følgt, og eit oversyn over prosessen er presentert i figur 1. Her listar vi også opp dei ulike inklusjonskriteria i fase to og tre som vert grundigare presenterte nedanfor.

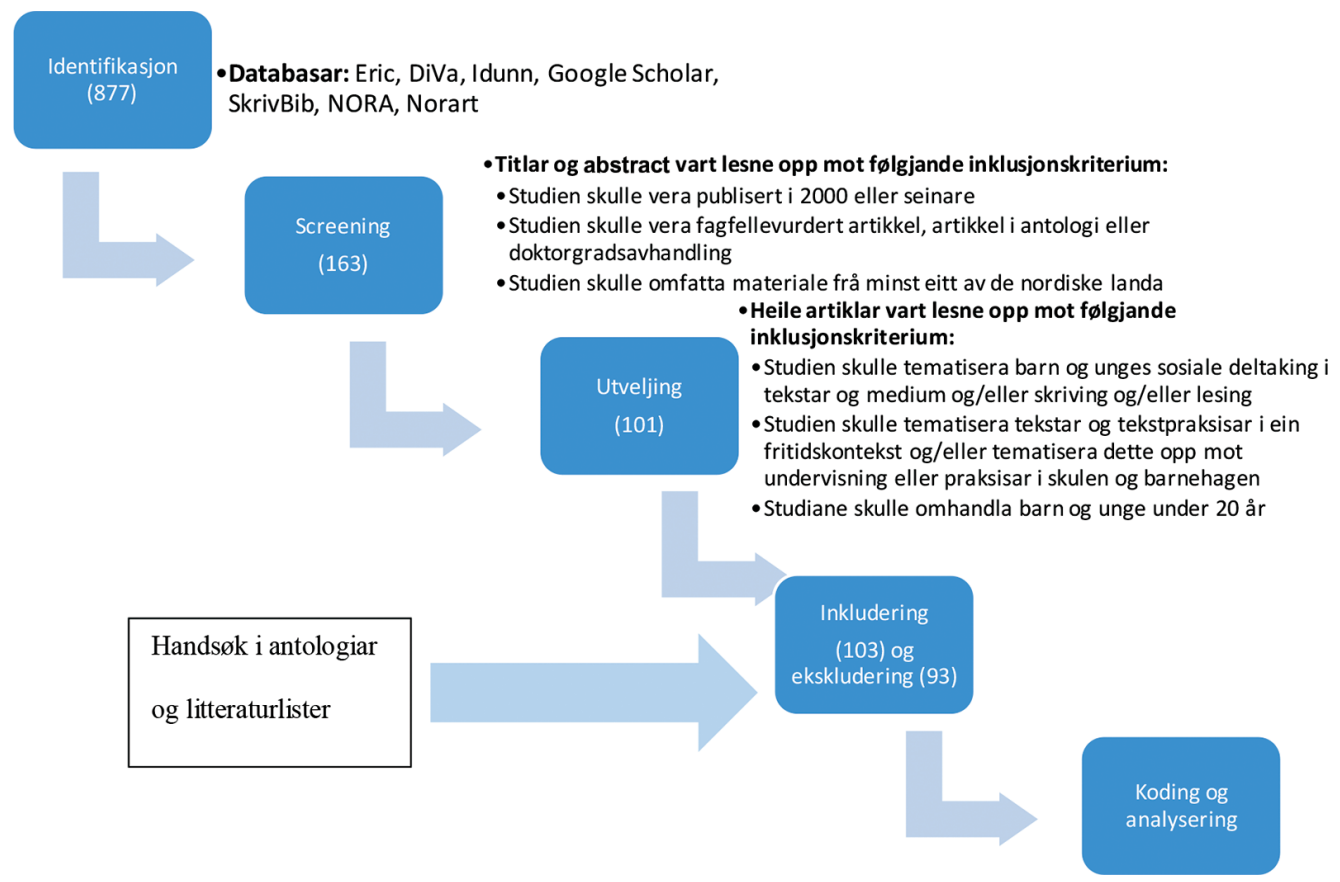

Figur 1. Oversikt over søkedatabasar, an tal studiar og inklusjonskriterium i dei ulike fasane 


\section{Søkjeprotokoll}

For å laga ein god søkjeprotokoll (sjå figur 2), gjennomførte vi først ein såkalla scoping (Prøitz, 2015, s. 12). Det vil seia at vi testsøkte kvar for oss i ulike databasar. Vi prøvde med ulike kombinasjonar av orda barn, unge, fritid, medier, tekst, literacy og deltaking på både engelsk og norsk i tre databasar, Idunn, Eric og Google Scholar, for å danna oss eit inntrykk av kva slags søkjeord som kunne fungera for å få relevante treff. Vi fann ut at dei same ordkombinasjonane ikkje gav like gode treff i alle databasene. I Google Scholar gav strengen "children OR youth AND vernacular OR “out of school” AND text AND literacy AND media» og tidsrom 2004-2019, heile 17500 treff, der mange såg relevante ut. Vi prøvde då «literacy AND text AND media AND participation AND nordic (children OR youth) AND (vernacular OR “out of school”)" og tidsavgrensing 2000-2019. Det gav 12700 treff. I Idunn var det kombinasjonen «children AND media AND participation AND literacy» som såg ut til å gje mest relevant resultat. Dette søket gav 101 treff som såg relevante ut. Det same søket i Eric gav 159 treff. På grunn av svært mange treff i Google Scholar, valde vi å skumlesa dei 400 første titlane og abstracta. Sidan Google Scholar gjev svært mange treff, fungerte dette søket også som ein «etterkontroll» på at vi hadde fått med oss relevante artiklar i dei andre søka.

\begin{tabular}{|l|l|l|}
\hline Språk & Deskriptor & Nøkkelord \\
\hline Norsk/svensk/dansk & $\begin{array}{l}\text { barn, unge/unga, ungdom, } \\
\text { tenåringer/tonåringar/ } \\
\text { teenagers }\end{array}$ & $\begin{array}{l}\text { AND fritid, hjemme/heime, } \\
\text { deltakelse/deltaking, literacy, } \\
\text { medier, frivillig }\end{array}$ \\
\hline Engelsk & $\begin{array}{l}\text { child, children, youth, } \\
\text { teenagers }\end{array}$ & $\begin{array}{l}\text { AND out of school, verna- } \\
\text { cular, participation, media, } \\
\text { literacy, media, nordic }\end{array}$ \\
\hline
\end{tabular}

Figur 2. Søkjeprotokoll

\section{Inklusjon og eksklusjon i fyrste fase (screening)}

I den fyrste utveljingsfasen skumlas vi artiklar og abstract vi hadde fått treff på i dei ulike databasane. Inklusjonskriteria var:

- Studien skulle vera publisert i 2000 eller seinare

- Studien skulle vera fagfellevurdert artikkel, artikkel i antologi eller doktorgradsavhandling

- Studien skulle omfatta materiale/empiri frå minst eitt av dei nordiske landa

Artiklar som ikkje var empiriske, sorterte vi vekk. Dette kunne til dømes vera artiklar som hadde som hovudføremål å drøfta digitale samfunnsendringar eller å drøfta særskilde omgrep kopla til digital utvikling og læring. Bokomtalar, føreord eller artiklar 


\section{G. K. Fuuhl \& M. Michelsen}

som tematiserte foreldrehaldningar til eigne barns bruk av teknologi, vart også sorterte bort. Artiklar utan nordisk empiri vart også ekskluderte. Til saman ekskluderte vi 714 tekstar i denne fasen.

\section{Inklusjon og eksklusjon i andre fase (utveljing)}

I den andre utveljingsfasen nærlas vi heile artiklar, og det var då råd å undersøkja om artiklane faktisk tematiserte tekstar og tekstpraksisar på fritida og barn og unges deltaking. Inklusjonskriterium var:

- Studiane skulle tematisera barn og unges sosiale deltaking i tekstar og medium og/ eller skriving og/eller lesing

- Studien skulle tematisera tekstar og tekstpraksisar i ein fritidskontekst og/eller tematisera dette opp mot undervisning eller praksisar i skulen og barnehagen

- Studiane skulle gjelda barn og unge under 20 år

I denne fasen ekskluderte vi empirisk forsking om den digitale aktiviteten eller kunnskapane til lærarar eller klasseleiing i digitale omgjevnader (sjå t.d. Marklund \& Dunkels, 2016 for undersøking om kva haldningar pedagogen har til bruk av nettbrett i barnehagen). Artiklar om bruk av digitale verktøy i klasserommet utan diskusjonar om koplinga til barn og unges tekstpraksisar på fritida vart også ekskluderte. Det same gjaldt artiklar som primært tok for seg munnlege praksisar (t.d. Engblom, 2004), eller artiklar som studerer tekstar utan å trekkja inn barn og unges deltaking $\mathrm{i}$ dei, som tekstanalyse av kommersielle abc-appar (t.d. Kvåle, 2020). Det er òg verdt å nemna at det finst forsking på mediert barndom (t.d. Drotner, 2005) eller forsking på digital mobbing eller nettrisikoar der literacy-perspektivet ikkje står sentralt (t.d. Staksrud, 2013). Slike studiar har vi ekskludert. Når det gjeld alder, så er det nokre studiar der ein kan anta at det er ungdom eller unge vaksne som er studieobjekt, men der alder ikkje vert spesifisert (sjå t.d. Veum, 2013; Aarseth, 2008). Desse har vi inkludert om ein kan anta at det er ungdom eller svært unge vaksne under 20 år som er deltakarar. Nokre forskarar nyttar den same eller liknande empiri i fleire av sine forskingsarbeid. Det som er tatt med i litteraturoversikta i denne reviewen, må derfor sjåast som døme på aktuelt forskingsarbeid som desse forskarane har gjort på feltet, og ei slik utveljing er gjort av plassomsyn.

\section{Koding}

For dei 93 artiklane og forskingsarbeida som stod att til slutt, oppretta vi ein tabell der vi skreiv inn detaljert informasjon om kvar av tekstane. I arbeid med tabellen gjorde vi òg ein siste eksklusjon av ti artiklar som ved nærare lesing synte seg mindre relevante, fordi dei primært handla om skule. Opplysningar vi noterte oss i denne tabellen var forfattarnamn, publiseringsår, tittel, kva for eitt av dei nordiske landa empiri var samla frå, forskingsspørsmål, metode, aldersgruppe på dei barna og ungdomane som var deltakarar i forskinga og funn. Informasjonen i tabellen gav oss høve 
til å få detaljert oversikt over materialet, og han vart brukt som eit utgangspunkt for dataanalysen.

\section{Resultat}

I denne delen gjev vi først ei kort oversikt over kva forskarane innanfor feltet barn og ungdoms fritidstekstar og fritidstekstpraksisar ønskjer å undersøkja, og kva slags empiri dei har samla inn. Deretter ser vi på kva metodar og teori som er nytta i forskinga. Til slutt går vi noko grundigare inn $\mathrm{i}$ empirien til forskarane og ser perspektiv og funn i dei ulike studiane opp mot kvarandre. Denne delen er vigd mest plass fordi han kan seia noko om kva tendensar som er rådande i forskinga.Vi meiner det skil seg ut tre hovudtendensar. Desse har vi kalla skuleperspektivet, tekstperspektivet og deltakingsperspektivet. Det er ikkje vasstette skott mellom dei ulike kategoriane. Til dømes kan studiar som er orienterte mot skulen, samstundes vera tekstnære i den forstand at det førekjem nærlesingar av dei enkelttekstane som barna nyttar eller lagar i klasserommet (sjå t.d. Haakedal, 2010). Kategoriseringa er fyrst og fremst basert på at forskingsprosjekta som er tekne med i denne reviewen i større eller mindre grad har eitt (eller fleire) av dei tre perspektiva.

\section{Kva slags empiri vert samla inn?}

Eit gjennomgåande trekk når det gjelder empirien i den eksisterande forskinga, er at aktivitetar er meir vanleg å studera enn tekstar. Dette kan vi hevda fordi observasjon er ei meir nytta tilnærming enn tekstanalyse (sjå under). Det er ei tung vekting mot digitale tekstaktivitetar (sjå t.d. Carlsen, 2013; Hoel \& Tønnesen, 2019; Juuhl, 2014; Nyjordet, 2010; Veum, 2013), men teikning og papirbaserte tekstar vert òg undersøkt i nokon grad (Hopperstad, 2013, 2016; Lindstrand, 2011). Ein annan tendens er at det vert samla inn ein god del empiri om bruk av teknologi i undervisningssituasjonar. Her er forskarane opptekne av tekstar, teknologi og medium som barn og unge har erfaring med frå fritida, slik som til dømes Internett (sjå t.d. Blikstad-Balas, 2012) eller dataspel (sjå t.d. Silseth, 2012), og kva slags tekstkompetanse og teikn på læring barn og unge viser fram i slike samanhengar. Nokre studiar er meir knytt til uformell teknologibruk og tekstskaping, t.d. i friminuttet eller i ikkje-lærar-styrte aktivitetar (sjå t.d. Björkvall \& Engblom, 2010; Malmbjer, 2012). Ein tredje tendens er at forskarane samlar inn eit større kvantitativt materiale som viser kva slags tekstar og medium barn og unge finn meiningsfulle i eige liv (sjå t.d. Wernholm, 2018).

Studiane fordeler seg utover aldersgruppene vidaregåande (25), ungdomsskule (17), barneskule (28) og barneheagealder (26). ${ }^{1}$ Aldersspenna er ulike i desse aldersinndelingane, men spreiinga fortel likevel at ingen aldersgrupper er tydeleg

\footnotetext{
${ }^{1}$ Sidan nokre artiklar har teke utgangspunkt i aldersgrupper som strekkjer seg over fleire av kategoriane i dette forskingsoversynet, vert det samla talet på studiar i ulike alderskategoriar høgre enn det samla talet på artiklar.
} 


\section{G. K. Fuuhl E M. Michelsen}

underforska. Det er ei nokså skeiv vekting av empiri frå ulike land: Vi fann 53 forskingsarbeid med empiri frå Noreg, 25 frå Sverige, 8 frå Finland og 7 frå Danmark. Det er oppsummert tidlegare at det er tette band mellom norsk og svensk tekstforsking, og dette gjer truleg at vi har betre oversyn over svensk forsking enn dansk og finsk. Fleire av kanalane vi har søkt i som er erklært nordiske, har også vore noregsbaserte (Nordic Fournal of Literacy Research, Skriv! Les!-konferansen, SkrivBib), og dette kan ha favorisert norsk forsking. Når det gjeld finsk forsking, har vi på grunn av manglande språkkompetanse også berre lese engelskspråklege artiklar, og det kan vera ein grunn til at vi berre har sett eit utsnitt. Dette kan òg seiast å vere ei avgrensing ved denne reviewen. Kvifor vi har funne så lite danskbasert forsking på barn og ungdoms fritidstekstar og -praksisar, veit vi ikkje.

\section{Kva slags metodar vert nytta?}

Observasjonsstudiar førekjem oftast. I heile 52 av studiane nyttar ein ulike former for observasjon. Videoobservasjon førekjem hyppig (sjå t.d. Björklund, 2008; Bjørgen, 2010; Carlsen, 2013; Maagerø, 2013; Sandvik, Smørdal \& Østerud, 2012; Wernholm, 2019; Åberg, Lantz-Andersson \& Pramling, 2015; Aarsand, 2010). Deltakande observasjon (sjå t.d. Andersson \& Sofkovha-Hashemi, 2016; Björkvall \& Engblom, 2010; Fast, 2007; Jæger, 2013; Karrebæk, 2013) og online-observasjon (Lantz-Andersson, 2015) førekjem også. Denne måten å samla inn data på gjev høve til å følgja tekstskapingsprosessar eller å undersøkja korleis barn og unge samhandlar med tekstar, skrivereiskapar eller skjermar. Skjermopptak eller registrering av tekstleg aktivitet på andre måtar, f.eks. hovudkamera, er også nytta i nokre studiar (Blikstad-Balas, 2012; Michelsen, 2016).

Vidare er intervju også brukt i ein del studiar (26), gjerne med føremål om å finna ut kva barn og unge tenkjer og meiner om eigne praksisar (sjå t.d. Bjørgen, 2010; Brevik, 2016; Dimitrov-Devold, 2017; Forsman, 2017). Eit eksempel er Dimitrov-Devold (2017) som undersøkjer kva slags digitale kompetansar unge, kvinnelege bloggarar opplever som meiningsfulle knytt til eigen bloggproduksjon. Som oftast vert intervju brukt i kombinasjon med andre metodar, gjerne videoobservasjon eller deltakande observasjon, men andre kombinasjonar førekjem også. Eit døme er Brevik (2016) som undersøkjer kvifor ei gruppe elevar les betre engelsk (som er deira L2-språk) enn norsk (som er deira L1-språk). Ho kombinerer intervju, der eleverfaringar med dataspel vert tematisert, med ei kvantitativ spørjeundersøking og data frå nasjonale leseprøver.

Tekstanalyse førekjem i 26 av studiane (sjå t.d. Björkvall \& Engblom, 2010; Hoel, 2018; Veum, 2013), gjerne med fokus på samspelet mellom ulike modalitetar og semiotiske ressursar. I Hoels (2018) artikkel om Erling på 5 år som lagar ei forteljing om storebroren sin, vert til dømes samspelet mellom lyd, skrift, fargar og bilete i teksten til Erling undersøkt. I nokre prosjekt er tekstar samla inn, utan at dei vert utsette for tekstanalyse. Det gjeld t.d. Andersson \& Sofkovha-Hashemi (2015). I desse studiane vert tekstane altså behandla som noko sekundært. 
Spørjeundersøking (gjerne til elevar og som dei fyller ut på skulen) med spørsmål om fritidspraksisar (ofte digitale) er også ein datainnsamlingsmetode som er i bruk. Dette gjeld til dømes Erstad og Gilje (2008), Ilomäki, Taalas og Lakkala (2012) og Nygren og Bjørgen (2010). Med spørjeundersøkingar får ein tak i rapportert praksis og rapporterte oppfatningar. Ein får data frå ei større mengd deltakarar, men får ikkje studert praksisar og tekstar direkte. I to av dei nemnde studiane er spørjeundersøking kombinert med forskingsmetodar som let ein koma nærare praksisane (sjå Ilomäki, Talaas \& Lakkala, 2012; Nygren \& Bjørgen, 2010). Det er eit par prosjekt som skil seg ut metodisk fordi dei ikkje tek i bruk observasjonar, tekstanalysar, spørjeundersøking eller intervju, men i staden baserer seg på at deltakarane rapporterer til forskaren gjennom å skriva dagbok over tidsbruk på ulike aktivitetar, som til dømes Jensen (2017).

Vi ser at det er brukt ei brei vifte av kvalitative og tekstorienterte metodar i forskinga. Noko kvantitative metodar, som spørjeundersøking, er også i bruk (sjå t.d. Kotilainen \& Suoninen, 2013). Generelt er feltet prega av metodetriangulering, der fleire metodar vert kombinerte for å få fleire inngangar til, og dermed meir heilskaplege forståingar av fenomen knytt til tekstpraksisar. Dette er òg er i tråd med Björkvall og Engbloms (2007, s. 97) bakgrunnsrapport og det dei har kalla «kommunikasjonsetnografi».

Dei fleste studiane undersøkjer tekstpraksisar over ein kortare periode, til dømes gjennom nokre undervisningsøkter eller gjennom ein tekstproduksjonsprosess, men det finst også studiar som strekkjer seg over meir enn eit år (Fast, 2007; Svensson, 2014). Likevel skil Tønnessen (2007) seg ut med hennar longitudinelle generasjonsstudie av barn og unges mediebruk gjennom tolv år. Utforsking og forståing ser ut til å vera prioritert i forskinga framfor å telja førekomstar og å generalisera. Dette funnet må sjåast i samanheng med at det også vert laga kvanititative kartleggingsrapportar om mediebruk av styresmaktene i dei ulike landa og EU, og informasjon herfrå vert ofte vist til som ein bakgrunn for djupneundersøkingane som vert gjort i mange forskingsarbeid. Døme på slike rapportar er Ungar og medier-rapporten (Statens medieråd, 2019) i Sverige, Barn og medier-rapportane (sjå t.d. Medietilsynet, 2016), i Norge, Children's media barometer-rapportane (sjå t.d. Suoninen, 2013) i Finland og rapportane frå prosjektet EU Kids Online (sjå t.d. Smahel, Machackova \& Mascheroni, 2020).

\section{Kva slags teori ligg til grunn for forskinga?}

Det er eit gjennomgåande trekk at studiane som gjeld tekstpraksisar dreg vekslar på new literacy studies og/eller sosiokulturell læringsteori (sjå t.d. Andersson \& Sofkova-Hashemi, 2016; Bjørgen \& Erstad, 2015; Svensson, 2014; Talaas, 2016; Tønnesen \& Hoel, 2019). Dette er i tråd med internasjonale tendensar (jf. Schultz, Hull \& Higgs, 2016). Studiane som gjeld tekstar byggjer i stor grad på sosialsemiotikk, særleg multimodal teori (sjå t.d. Forsman, 2017; Gilje, 2010), men det finst også studiar som nyttar andre teoretiske perspektiv, som retoriske (Juuhl, 2014), sosiolingvistiske (Bellander, 2010) og dialogiske (Pietikäinen \& Dufva, 2014). 


\section{G. K. Fuuhl \& M. Michelsen}

Hovudtendensen er altså at teknologi, teikn og tekstar vert sett på som reiskapar til å læra med, å tenkja med eller å oppnå bestemte føremål med. Når det gjeld unntak frå denne hovudtendensen, finst det nokre få studiar som dreg vekslar på nettverksteori (sjå Stuedahl \& Smørdal, 2011) eller meir (skule-)fagspesifikke tilnærmingar, som språktileigningsteoriar (Aniol, 2011; Brevik, 2016; Jensen, 2017) eller skrivemotivasjon (Bjørkvold, 2013).

\section{Kva funn vert presenterte?}

Forskinga på barn og ungdoms fritidstekstar og tekstpraksisar er mangslungen, og difor kan funna i dei 93 studiane vera vanskelege å samanlikna. For å rydda noko, har vi difor sortert funna ut i frå dei tre ulike perspektiva vi har funne i materialet. Desse er baserte på kva hovudærendet til studiane tykkjest å vera: om studien undersøkjer barn og ungdoms fritidstekstar og -praksisar i eit skuleperspektiv, om studien undersøkjer tekstar, eller om studien undersøkjer aktivitetar eller deltaking. Fleire studiar gjer fleire ting, og kan såleis plasserast i fleire kategoriar, men alle studiane kan plasserast i minst ein kategori.

\section{Skuleperspektivet: Fritidsliteracy som del av tekstpraksisar i skulen}

Ei stor overvekt av studiane som tematiserer barn og ungdoms fritidstekstpraksisar og/eller fritidstekstar, gjer det i relasjon til skulekonteksten. Forskinga med eit skuleperspektiv gjev svar på kva literacy i fag og undervisningssituasjonar kan vera, og korleis denne læringa er knytt til språk og modalitetar på ulike måtar. Forskinga gjev innsikt i korleis språk og tekstar på fritida liknar på eller skil seg frå språk og tekstar i faglege samanhengar.

Tematiseringa av fritidstekstpraksisar i relasjon til skulekonteksten skjer på fleire måtar: Det kan handla om at literacypraksisar frå fritida gjer seg gjeldande på skulen, som i ein hovudkamerastudie av Blikstad-Balas av korleis elevar brukte internett på ein fritidsmåte i undervisninga (2012), eller Karrebæk sin studie av fotballkort si rolle i ein gut sitt arbeid med bokstavtileigning (2013). Det kan handla om skriveaktivitetar på skulen som er frivillige, men usynlege, slik som når ein elev skriv på eige initiativ i friminuttet (Malmbjer, 2012). Denne artikkelen peikar også på korleis sjølve føremålet med skrivinga er ein sentral motivasjon for skrivinga: Eleven skriv nemleg av ei side i ei kokebok fordi han skal heim og baka muffins saman med faren. Studiar som tematiserer barn og ungdoms fritidstekstpraksisar og -tekstar i ein skulesamanheng, kan også handla om at lærarar, anten som del av den vanlege undervisninga, eller som eit forsøk, brukar ulike digitale og sosiale medium eller digitale verktøy som elles er vanlege i ein fritidskontekst, i opplæringa, og der lærar og/eller forskar vurderer dette som ein måte å minka gapet mellom skule og fritid på. Dette er veldig mange studiar, og desse har vi som tidlegare nemnt berre inkludert dersom dei også tematiserer fritidstekstpraksisar på andre måtar. Det er òg viktig å nemna at det finst studiar som tek empirisk utgangspunkt i skulen, til dømes for rekruttering av deltakarar, men som har fritidstekstpraksisar som objekt for undersøking, og/eller 
der ein undersøkjer skilnader og likskapar mellom tekstpraksisar i og utanfor skulen (sjå t.d. Erstad \& Gilje, 2008; Gilje \& Silseth, 2016; Ilomäki, Talaas \& Lakkala, 2012; Juuhl, 2014; Nygren \& Bjørgen, 2010; Svoen \& Gilje, 2012, som alle har desse to karakteristikkane felles).

Studiar frå Finland og Danmark rapporterer om stor avstand mellom digitale literacypraksisar i skule og fritid (Ilomäki, Talaas \& Lakkala, 2012; Sørensen, 2005). Norske studiar rapporterer også om gap mellom skule og fritid, men nyanserer biletet med at nokre praksisar er overlappande, og at for nokre elevar er det band der det er gap for andre (Erstad \& Gilje, 2008; Juuhl, 2014). Vidare finst det også studiar som framhevar potensialet for skulen i å byggja på barns uformelt tileigna digitale ferdigheiter (sjå t.d. Sørensen, Danielsen \& Nielsen, 2007). Det finst også nokre studiar som fokuserer på ungdoms deltaking i literacypraksisar knytt til opplæringsprogram utanfor skulen (Erstad et al., 2009; Kotilainen, 2009; Kotilainen \& Rantala, 2010).

Blikstad-Balas var kritisk til måten fritidsliteracypraksisar fekk rom i skulen på (på vidaregåande), fordi det at ungdom brukte tida på ikkje-faglege ting medan det føregjekk undervisning, gjorde at dei ikkje fekk med seg undervisninga. Ressursperspektivet ser likevel ut til å dominera i forskinga vi har funne på korleis fritidsliteracypraksisar vert aktiverte og kan aktiverast i skulen (sjå t.d. Erstad, Gilje \& de Lange, 2007; Gilje \& Silseth, 2016; Lantz-Andersson, 2017; Laursen \& Daugaard, 2012).

Denne forskinga gjev ikkje eit eintydig svar på om barns teksterfaringar har overføringsverdi og kan vera viktige i formelle læringssituasjonar. Den gjev tvert imot mange ulike svar, og det kan sjå ut til at nokre barn og ungdomar sine fritidsliteracyerfaringar vil vera nyttige i nokre skulesamanhengar (sjå t.d. Björkvall \& Engblom, 2010; Erstad, Gilje \& de Lange, 2007; Gilje, 2007; Jensen, 2017; Lantz-Andersson, 2017), medan nokre vil kunne stå i konflikt med nokre skulske mål (jf. BlikstadBalas, 2012, sjå også Erstad et al., 2009; Skaar, 2011). Mange studiar peikar på at det at barnehagen og skulen viser interesse for tekstar og literacyerfaringar barn tek med seg heimanfrå, har verdi som ei anerkjenning av barnet (sjå t.d. Fast, 2007; Karrebæk, 2013; Nygren \& Bjørgen, 2010).

\section{Tekstperspektivet: Diskursar, prosessar og tekstprodukt}

Studiar som brukar barn og ungdoms tekstar som empiri, har vi sortert under tekstperspektivet. Det er særleg tekstar som barn og unge skapar som får merksemd. Når det gjeld empiri som er samla inn med tanke på å undersøkja barns tekstproduksjon, så vert både digitale og papirbaserte tekstar samla inn, men det er som nemnt tidlegare, ei vekting mot dei digitale tekstane. Døme på digitale tekster som barn og unge produserer, og som vert forska på, er eksempelvis SMS (Iversen, 2009; Ringdal, 2002) og chat (Bellander, 2010; Svennvig \& Johansen, 2011; Sørensen, 2001), profilsider i nettsamfunn (Skaar, 2010), teiknefilm (Maagerø, 2005), biletbok (Jæger, 2013), blogg (Bellander, 2010; Juuhl, 2014; Veum, 2013), multimodale tekstar på Snapchat og Instagram (Undrum \& Veum, 2018). Denne forskinga viser korleis barn og unge lagar tekstar som er knytte til premissar og sjangerforventningar i format 


\section{G. K. Fuuhl E M. Michelsen}

som er tilgjengelege og populære i det aktuelle tidsrommet og for den aktuelle aldersgruppa. Studiane viser også korleis «kva som er tilgjengeleg og populært» har endra seg i perioden, frå t.d. anonyme chatterom som var mykje omtala på tidleg 2000-tal (sjå t.d. Sørensen, 2001), til blogging, chatting med vener og multimodale tekstar delte i ulike sosiale medium. Denne forskinga er også i større grad enn forsking innafor skuleperspektivet vigd til praksisar som ikkje like lett kan koplast til skulen.

I nokre tilfelle vert likevel tekstskaping i klasserommet, og korleis elevane tar i bruk semiotiske ressursar frå fritidskulturen, tematisert. Eit eksempel på ein slik studie er Haakedal (2010), som undersøkjer korleis elevar framstiller disiplar i elevarbeidsbøker i KRLE. Ho finn at disiplane framstår som hybridar mellom lærebokas framstilling av disiplar og fritidskulturens superheltar.

Studiar av barns tekstproduksjon kan delast opp i studiar som undersøkjer og analyserer tekstane (t.d. Haakedal, 2006; Veum, 2013), studiar som fyrst og fremst studerer produksjonsprosessen (til dømes Erstad, Gilje \& de Lange, 2007), og nokre som prøver å gjera begge delar (t.d. Bellander, 2010; Björkvall \& Engblom 2010). Studiar av mindre barn sine tekstar er ofte samstundes studiar av produksjonsprosessen (sjå t.d. Fast, 2007; Hoel, 2018; Hopperstad, 2013; Jæger, 2013; Karrebæk, 2013; Åberg, Lantz-Andersson \& Pramling, 2015). Dette kan kanskje knytast til at for mindre barn er snakkinga undervegs i produksjonsprosessen i større grad rimeleg å sjå som ein del av teksten enn hjå eldre barn (Hopperstad, 2013). Når det gjeld aktivitetar som i større grad er kopla til papirmediet, finst det fleire studiar av korleis barn teiknar eller skapar andre tekstar i barnehagen, åleine eller saman med andre (sjå t.d. Hopperstad, 2013, 2016; Lindstrand, 2011; Maagerø, 2012). Ein sjanger som har fått merksemd i samband med barns tidlege literacy-tileigning er også til-og-frå-tekstane, det vil seia tekstar som barn gjerne skriv med foreldra eller andre nære personar i tankane (Evensen, 2013; Lorentzen, 2002; Matre, Sjøhelle \& Solheim, 2012). Mange av dei innsamla tekstane i slike studiar er papirbaserte. Andre papirbaserte tekstar som er studerte, er m.a. dagboksnotat, lister og fargeleggingsark (Matre, Sjøhelle \& Solheim, 2012; Michelsen, 2016; Semundseth, 2006).

Forsking innafor tekstperspektivet gjev også innsikt i kva for tekstlege aktivitetar som er viktige i barn og unges liv, og korleis frivillige skrive- og lesesituasjonar kan innebera læring. Vidare gjev forskinga innsikt i kva slags sjangererfaringar nordiske barn har, og korleis tekstane er kopla til erfaringar, kunnskapar og konkrete kvardagssituasjonar. Dette perspektivet innafor forskinga gjev med andre ord svar på kva barn og unge er interesserte $\mathrm{i}$ å lesa og skriva om som $i k k j e$ nødvendigvis er relatert til skulearbeid. I Björkvall og Engbloms (2010) studie av korleis 7-8-åringar nyttar teknologi i klasserommet, vert til dømes tekstanalyse av elevskapte skjermtekstar nytta for å undersøkja læringspotensialet i både formelle og uformelle klasseromssituasjonar. Dei finn at det ikkje er skjermaktiviteten i seg sjølv som bidreg til læring, men at det kan vera læringspotensial i både dei formelle og i dei uformelle situasjonane. Dei påpeikar samstundes at dei uformelle situasjonane, anten dei vert verdsette av læraren eller ikkje, er undervurderte som kjelde til læring. 
Denne forskinga gjev òg innsikt i kven barn og unge er interesserte i å kommunisera med, kva slags føremål kommunikasjonen har, og kva som kan motivera barn og unge til å ytra seg og skapa tekstar av ulike slag. Når det gjeld den sosiale sida ved tekstar, vert gjerne det mellompersonlege aspektet løfta fram, og forskarane er opptekne av å finne ut korleis barn og unge vender seg målretta mot reelle mottakarar $\mathrm{i}$ autentiske situasjonar (sjå t.d. Ringdal, 2002). I denne forskinga vert ofte dei diskursane barn og unge dreg vekslar på, tematiserte. Veum (2013) viser til dømes korleis fire unge jentebloggarar vender seg mot blogglesarane sine. Ho finn at bloggarane har ei dobbel avsendarrolle. Dei framstiller seg sjølve både som nær og personleg ven og som profesjonell aktør (Veum 2013, s. 118). Vidare er bloggane vovne inn i diskursar kopla til forbruk og kommersialisme.

\section{Deltakingsperspektivet: Samspel mellom kontekst, tekst, teknologi og deltakarar}

Studiar som fyrst og fremst studerer aktiviteten eller deltakinga, har vi plassert under dette perspektivet. Her finn ein studiar av ulike skjerm- og tekstskapingsaktivitetar, og felles for desse studiane er at dei ikkje berre legg vekt på tekst eller produkt, men sjølve lese- og skriveaktiviteten, bruk av teknologi og konteksten rundt deltakarane, slik som samspelet med andre barn eller vaksne (sjå t.d. Carlsen, 2013; Hernwall, 2001; Leinonen \& Sintonen, 2014; Nyjordet, 2010; Petersen, 2015; Aarsand, 2007), eller læringsvegar gjennom eit spel (Silseth, 2015).

Når det gjeld dei yngste barna, er det innanfor ein barnehagekontekst vanleg å undersøkja samspelet deira med dei vaksne, andre barn og produksjon av eigne tekstar (sjå t.d. Lindstrand, 2011, 2015; Maagerø, 2013; Sandvik, Smørdal \& Østerud, 2012; Åberg, 2018). Desse studiane viser kor viktig støtte frå dei vaksne er, også for dei tekstane som barna eventuelt skapar (Hopperstad, Lorentzen \& Semundseth, 2009; Leinonen \& Sintonen, 2014; Åberg, Lantz-Andersson \& Pramling, 2015). Fokuset i desse studiane kan også vera å sjå på kva slags kompetansar barn tek med seg inn i tekstskapinga. Eksempelvis studerer Sandvik, Smørdal \& Østerud (2012) bruk av iPad i ein multikulturell barnehage, og korleis barna dreg vekslar på eigen narrativ kompetanse når dei skapar sine eigne digitale tekstar. Eit eksempel på forsking som er gjort i heimen, og som studerer samspelet mellom to barn framfor skjermen, er Nyjordets (2010) artikkel om to 5-åringars møte med nettstaden til NRK Super. Trass $i$ at desse barna si navigering i nett-teksten kan verka fragmentarisk sett frå utsida, tolkar og brukar dei teksten på ein måte som gjev meining for dei sjølve. Jæger (2016) og Juuhl (2017) har òg undersøkt liknande tekstpraksisar i heimen. Det finst også fleire etnografiske studiar som fylgjer barn og literacyerfaringane deira i ulike kontekstar. Eit funn hjå fleire er at barn deltek i eit mangfald av literacyhendingar saman med andre barn og vaksne $\mathrm{i}$ heimen og i barnehage/skule, og at barna opplever desse som meiningsfulle. Likevel vert ofte dei kvardagslege literacyerfaringane og -kompetansane til barna, særleg dei som er knytt til andre språk enn det offisielle og til populærkultur, oversett 


\section{G. K. fuuhl \& M. Michelsen}

og/eller avviste av utdanningsinstitusjonane (Duek, 2017; Fast, 2007; Karrebæk, 2013).

Fleire studiar undersøkjer korleis barn og ungdom i skulealder deltek i ulike digitale literacyaktivitetar saman med andre på fritida, til dømes gjennom spel (Dralega \& Corneliussen, 2018; Wernholm, 2018; Aarsand, 2007, 2010) og gjennom sosiale medium (Bergander, 2015; Hilmarsen \& Arnseth, 2017; Lüders, 2007; Wernholm, $2018,2019)$. Aarsand har studert kva rolle digitale spel har i livet til barn, giennom m.a. studiar av forhandlingar om spelkonsoll $i$ heimen, korleis utrop og anna verbalspråk undervegs i spelinga skaper ei felles oppleving med dei andre dei speler med, og korleis gutars spel-literacy er ein ressurs i interaksjon med jamaldringar (2007, 2010). Wernholm har studert kva som pregar 9-12-åringars deltaking i digitale fellesskapar knytt til både spel og sosiale medium, og funne ulike måtar å delta på, frå venskapsbasert til meir spesialiserte, knytt til å utøva interesser, byggja kunnskap og skapa ting (2018). Det er òg i tråd med Michelsens (2016) etnografiske studie av korleis barn nyttar tekstar på fritida i og utanfor Internett. Hilmarsen og Arnseth har undersøkt korleis 14-åringars biletdeling på Instagram både viser literacy og er knytt til utøving av identitet og administrering av sosiale relasjonar (2017). DimitrovDevold har undersøkt kva slags kompetansar unge, kvinnelege bloggarar sjølve opplever som viktige å ha når dei bloggar (2017). Forsman har undersøkt tenåringars «selfie-literacy» knytt til kjønna sjølvrepresentasjonar. Felles for desse tre siste studiane er at dei viser at ungdom verdset det å kunna styra sjølvframstillinga si, og gjer mange tekstvurderingar som viser kompetanse knytt til dette (2017).

Studiar av ungdoms tekstpraksisar (gjerne i form av studiar av digitale praksisar) frå ulike felt gjev ein breiare kunnskap om nordiske ungdomars fritidstekstar og fritidstekstpraksisar. Som eit døme viser ein studie innan engelskdidaktikk at dansk ungdom som speler mykje engelskspråklege digitale spel på fritida, får auka det engelske ordforrådet (Jensen, 2016). Spelpraksisen vert også knytt til at ein del elevar (mest gutar) les betre på engelsk enn på morsmålet (Brevik, 2016). Desse studiane viser at endringar i ungdoms tekstpraksisar kan leia til kulturelle samfunnsendringar og endra språkkompetanse i befolkninga. På den måten utgjer dei eit verdifullt perspektiv på barn og ungdoms tekstpraksisar.

Sosiolingvistiske studiar av korleis fleirspråkleg ungdom brukar dei språklege ressursane sine til å uttrykkja og forhandla om tilhøyrsle og identitet får også fram tematikkar som er viktige for ungdom, og som er lite synleg i ikkje-sosiolingvistisk literacyforsking (sjå t.d. Cutler \& Røyneland, 2015; Dewilde, 2016, 2017; Røyneland, 2018). Wedin skriv frå eit new literacy studies-perspektiv om eit nærskylt tema: korleis unge asylsøkjarar brukar literacy i identitetsarbeid og for å utøva «agency» (2012).

Forsking med eit deltakingsperspektiv viser korleis ulike typar lesing og tekstskaping er innvove i livet til barn og ungdom, og kva desse aktivitetane og tekstane har å seia for barn og ungdom. Denne forskinga viser, i likskap med forskinga på tekstar, korleis barn og unge skriv og les med utgangspunkt i sosiale og personlege 
føremål, men han gir i større grad svar på korleis dei er samfunnsdeltakarar på andre måtar og i andre samanhengar enn i skulen og i heimen. Forskarane løfter òg fram korleis andre som barn og unge har sosial omgang med bidreg til læring og til forming av identitet, og forskarane drøfter òg i større grad enn forskarane innanfor tekstperspektivet omgang med teknologi.

\section{Oppsummering og diskusjon}

Eit trekk som pregar dei nordiske landa, er stor utbreiing av digitale medium og internett i heimane, noko som Björkvall \& Engblom trekte fram i sin rapport frå 2007. Dette er eit samfunnsmessig vilkår som framleis legg premissar for den nordiske forskinga. I nordisk samanheng gjeld mykje av forskinga på barn og ungdoms fritidstekstpraksisar digitale tekstpraksisar i skulen, barnehagen og heimen. Dette står delvis i kontrast til internasjonal forsking der tekstpraksisar knytte til ulike fritidstilbod for barn og ungdom kan sjå ut til å ha ein større plass. Eit døme er Sefton-Greens internasjonale forskingsoversyn om læring utanfor skulen, som i røynda er eit oversyn over forsking på institusjonar for læring etter skuletid (2013). Denne skilnaden kan truleg både knytast til materielle vilkår, til organisering av den nordiske kvardagen, og til ulike syn på barn og barndom.

Når det gjeld empiri, er det meir forsking på digitale tekstar enn på papirbaserte, både i og utanfor skulekonteksten. Ei avgrensing når det gjeld kva empiri denne metastudien har fanga opp, følgjer av søkjeorda. Når vi har brukt søkjeord som tekst, literacy og deltaking, men ikkje til dømes lesing, er det grunn til å tru at vi i mindre grad har dekt studiar som berre handlar om dei reseptive delane av tekstpraksisane til barn og ungdom, enn studiar der barn og ungdom sjølve er produsentar. Metodisk er det kvalitative metodar, og særleg observasjon, intervju og tekststudiar som dominerer, og ofte er fleire metodar kombinerte. Når det gjeld teoretisk orientering, er svært mange av forskarane opptekne av korleis nye literacy-erfaringar kan koplast på gamle, noko som er i tråd med eit sosiokulturelt læringsperspektiv. Det er dermed langt på veg ei felles forståing av at barn har med seg kunnskapar frå heimemiljø og fritid, og at dei bør få oppleva desse som gyldige på skulen (sjå t.d. Lorentzen, 2009, s. 104), men at kunnskapane òg må utfordrast eller kan koma i konflikt med skulepraksisar. At kvalitative studiar dominerer i forskinga, må også forståast med atterhald om at det kan vera at reine studiar av lesing ikkje er fanga opp. Kvantitative metodar har tradisjonelt ein større plass i leseforsking enn i andre delar av literacyforskinga.

Dei literacy-erfaringane barn og unge får på fritida, vert ikkje alltid anerkjende i utdanningsinstitusjonen. Ein diskusjon som går igjen i den nordiske literacy-forskinga på frivillige praksisar, har nettopp å gjera med korleis skulen anerkjenner, eller ikkje anerkjenner, barns frivillige læring. Eit poeng vi meiner det er svært viktig å trekkja fram frå studiane som tek føre seg barn og unges frivillige tekstaktivitetar utanfor skulen, er at barn og unges tekstkompetanse ikkje berre viser seg i dei produkta dei lagar, men i sjølve prosessen. Det er ofte den føremålsretta og samhandlande aktiviteten 


\section{G. K. Fuuhl E M. Michelsen}

som framstår som verdifull for barna sjølve, og som bidreg til læring. Dette er ei tankevekkjande innsikt fordi aktivitetens læringsverdi i fritidskulturen delvis står i kontrast til korleis eit produkt ofte er det som vert gjeve verdi i skulesamanheng. I formelle læringssituasjonar er det gjerne ferdig eller halvferdig produkt eller ei gjennomført oppgåve som vert sett på som uttrykk for kva eit barn kan eller har gjort.

Eit anna fellestrekk når det gjeld den teoretiske tilnærminga, er at mange studiar nyttar new literacy studies som tilnærming. Dette har den nordiske forskinga til felles med internasjonal forsking (jf. Schultz, Hull \& Higgs, 2016). Det ser også ut til å vera ein felles «bank» av engelskspråkleg forsking som vert referert til på tvers av lande- og disiplingrenser. Samstundes ser det ut til å vere relativt lite referansar over dei nordiske landegrensene, og lite referansar på tvers av disiplingrenser i Norden, på den måten at nordiske pedagogar, tekstforskarar, medieforskarar og språkforskarar i liten grad refererer til kvarandre. Disiplingrensene kan også sjåast som ein bakgrunn for dei tre ulike perspektiva vi har funne: skuleperspektivet kan knytast til pedagogikk og tekstperspektivet til språk- og litteraturdisiplinar, utan at dette er heilt eintydig - vi ser også ei interesse for å kombinera perspektiv, som til døme tekstanalyse og intervju om tekstar og -praksisar. Kanskje noko av det som skal til for at forsking på barn og ungdoms fritidstekstar og -tekstpraksisar skal kunna verta eit etablert forskingsfelt, er større fagleg nyfikne på forsking over disiplin- og nabolandsgrenser?

Funn frå både deltakings- og tekstperspektivet viser at skrivinga og lesinga på fritida er interessant for barn og unge fordi aktivitetane føregår saman med nokon, slik som når ein lagar digitale tekstar i barnehagen eller speler spel, eller fordi aktivitetane vert retta mot nokon, slik som når barn lagar til-og-frå-tekstar og lagar forteljingar til familiemedlemmer, eller når større barn og ungdomar deler minne med vener på Instagram og Snapchat. Vidare gjer den frivillige lesinga og skrivinga at ein kan oppnå noko eller vera nokon i eige liv. Når det gjeld eldre barn og ungdom, viser forskinga også det tette sambandet mellom kompetanse og interesse eller motivasjon. Fleire studiar viser at når barn diskuterer og vurderer tekstar som interesserer dei, særleg i sosiale medium, både eigne og andre sine, gjer dei vurderingar som viser ein nyansert multimodal tekstkompetanse. Denne metastudien må likevel lesast med dei atterhalda at materialet frå ulike land er noko skeivt, og at studiar avgrensa til å handla om lesing truleg i liten grad vil vera fanga opp. Dette har fylgjer for tolking av resultata.

Ein tendens i forskinga som kan problematiserast, er at forskarane er opptekne av å fanga vanlege tekstar og tekstpraksisar (jf. t.d. Arnseth \& Hilmarsen, 2017; Bellander, 2010, som både tematiserer at dei er ute etter det kvardagslege og vanlege). Dette kan gjera at tekstpraksisforskinga ikkje oppdagar mindre vanlege og kanskje problematiske tekstpraksisar, som også nokre ungdomar deltek i. Eitt døme er digital mobbing, eit anna aktuelt døme er høgreekstreme tekstpraksisar. I våre søk har vi ikkje funne studiar som handlar om t.d. høgreekstreme tekstpraksisar mellom ungdom, sjølv om vi veit at slike tekstpraksisar vert studert av andre forskingsfelt (sjå t.d. Wahlström \& Törnberg, 2019). Med interessa for det vanlege står forskingsfeltet i fare for å 
forsterka nokre sider ved ungdoms tekstpraksisar og oversjå andre. Dette bør mana til både audmjukheit for alt ein ikkje veit, og til meir tverrfagleg samarbeid.

Ein annan tendens som kan problematiserast, er overvekta av studiar knytt til digitale tekstar og praksisar. Overvekta av digitale tekstar som er studerte kan vera eit resultat av ein digitalisert kvardag, men også av eit ynske mellom forskarar om å fanga «det nye». Likevel meiner vi at eit føremål for vidare forsking bør vera å undersøkja barns kompetansar på tvers av digitale og analoge medium, og kanskje også følgja eit mindre tal barn i fleire kontekstar over lengre tid.

\section{Forfattaromtale}

Gudrun Kløve Juuhl er fyrsteamanuensis ved seksjon for norsk i lærarutdanninga på Høgskulen i Volda. Forskingsinteressene hennar er mellom anna barn og vaksne si friviljuge skriving, kvardagstekstar, retorikk og dialogisme.

Maja Michelsen er førsteamanuensis i norsk ved avdeling for lærerutdanning ved Høgskolen i Østfold. Hun forsker på barn, medier, literacy og multimodalitet og har blant annet skrevet doktorgradsavhandling om barns bruk av Internett.

\section{Litteratur}

Aarsand, P. (2007). Around the screen. Computer activities in children's everyday lives (Doktoravhandling, Linköpings universitet). Henta frå http://liu.diva-portal.org/smash/get/diva2:23606/FULLTEXT01.pdf

Aarsand, P. (2010). Young boys playing digital games. Nordic fournal of Digital Literacy, 5(1), 38-54. Henta frå https://www.idunn.no/dk/2010/01/art04

Andersson, P. \& Sofkova-Hashemi, S. (2016). Screen-based literacy practices in Swedish primary schools. Nordic Fournal of Digital Literacy, 11(2). Henta frå https://www.idunn.no/dk/2016/02/screen-based_ literacy_practices_in_swedish_primary_schools

Aniol, M. (2011). New media and new literacies: mapping extracurricular language competencies of Polish and Norwegian adolescents. I M. Kaczmarek (Red.), Health and well-being in adolescence: part two, Media (s. 101-123). Poznan: Bogucki Wydawnictowo Naukowe.

Arnseth, H. C. (2008). Dataspillet som lærings- og sosialiseringsarena. I S. Østerud \& E. Skogseth (Red.), A vcere på nett. Kommunikasjon, identitets- og kompetanseutvikling med digitale medier. Oslo: Cappelen.

Barton, D. \& Hamilton, M. (1998). Local literacies. Reading and writing in one community. London: Routledge.

Bellander, T. (2010). Ungdomars dagliga interaktion. En språkvetenskapelig studie av sex gymnasieungdomars bruk av tal, skrift og interaktionsmedier (Doktoravhandling, Stockholms universitet). Henta frå http://urn.kb.se/ resolve?urn=urn:nbn:se:uu:diva-132896.

Bergander, A. L. (2015). Att göra literacy online och offline: Digitala medier $i$ barns kamratkulturer (Doktoravhandling, Uppsala universitet). Henta frå https://www.diva-portal.org/smash/get/diva2:807202/ FULLTEXT01.pdf

Bjørgen, A. M. (2010). Boundary crossing and learning identities - digital storytelling in primary schools. Seminar.net, 6(2). Henta frå https://journals.hioa.no/index.php/seminar/article/view/2429

Bjørgen, A. M. \& Erstad, O. (2014). The connected child: tracing digital literacy from school to leisure. Pedagogies, 10(2), 113-127. https://doi.org/10.1080/1554480X.2014.977290

Björklund, E. (2008). Att erövra litteracitet: Små barns kommunikativa möten med berättande, bilder, text och tecken $i$ förskolan (Doktoravhandling, Göteborgs universitet). Henta frå http://hdl.handle.net/2077/18674

Björkvall, A. \& Engblom, C. (2007). Finns det nytta med nöje? Barns självvalda skärmbaserade textaktiviteter som resurs för lärande i skolan. I B.-L. Gunnarsson \& A.-M. Karlsson (Red.), Ett vidgat textbegrepp (s. 94-102). Henta frå https://www.diva-portal.org/smash/get/diva2:54389/FULLTEXT01.pdf 


\section{G. K. Fuuhl \& M. Michelsen}

Björkvall, A. \& Engblom, C. (2010). Young children's exploration of semiotic resources during unofficial computer activities in the classroom. Fournal of Early Childhood Literacy, 10(3), 271-293. https://doi.org/ $10.1177 / 1468798410372159$

Bjørkvold, T. (2013). Autentisk skriving i og utanfor klasserommet. I D. Skjelbred \& A. Veum (Red.), Literacy $i$ leringskontekster. Oslo: Cappelen Damm Akademisk.

Blikstad-Balas, M. (2012). Digital literacy in upper secondary school - What do students use their laptops for during teacher instruction? Nordic journal of digital literacy, 7(2), 81-96. Henta frå https://www.idunn.no/ dk/2012/02/digital_literacy_in_upper_secondary_school_-_what_do_studen

Brevik, L. M. (2016). The gaming outliers. I E. Elstad (Red.), Educational technology and polycontextual bridging. Rotterdam: SensePublishers.

Carlsen, M. (2013). Mathematical learning opportunities in kindergarten through the use of digital tools: Affordances and constraints. Nordic Fournal of Digital Literacy, 8(3), 171-185. Henta frå https://www. idunn.no/dk/2013/03/mathematical_learning_opportunities_in_kindergarten_through

Cutler, C. \& Røyneland, U. (2015). "Where the fuck am I from?»: Hip-hop youth and the (re)negotiation of language and identity in Norway and the US. I J. Nortier \& B. A. Svendssen (Red.), Language, youth and identity in the $21^{\text {st }}$ century. Linguistic practices across urban spaces (s. 139-163). Cambridge: Cambridge University Press.

Dewilde, J. (2016). «Det er bare i hjertet mitt»: Portrett av en transspråklig ungdom som diktskriver. Skandinaviske språkstudier, 7(2), 46.

Dewilde, J. (2017). Multilingual young people as writers in a global age. I B. Paulsrud, J. Rosén, B. Straszer \& Å. Wedin (Red.), New perspectives on translanguaging and education. Clevedon: Multilingual Matters.

Dimitrov-Devold, K. (2017). What matters to the girls? Norwegian girls' experiences of digital competences in mainstream blogging. YOUNG, 2, 190-207. https://doi.org/10.1177/1103308816673496

Dralega, C. A. \& Corneliussen, H. G. (2018). Gaming and identity constructuction among immigrant youth in Norway. I H. Hogset, D. M. Berge \& K. Y. Dale (Red.), Det regionale i det internasjonale (s. 187-205). Oslo: Universitetsforlaget.

Drotner, K. (2005). Mediatized childhoods: Discourses, dilemmas and directions. I J. Quortrup (Red.), Studies in modern childhood: Society, agency, culture (s. 39-58). London: Palgrave Macmillan.

Duek, S. (2017). Med andra ord. Samspel och villkor för litteracitet bland nyanlända barn Doktoravhandling, Karlstads universitet). Henta frå https://www.diva-portal.org/smash/get/diva2:1055930/FULLTEXT01. pdf

Engblom, C. (2004). Samtal, identiteter och positionering. Ungdomars interaktion $i$ en mångkulturell miljö (Doktoravhandling, Stockholms universitet). Henta frå http://su.diva-portal.org/smash/get/diva2:189616/ FULLTEXT01.pdf

Erstad, O. \& Gilje, Ø. (2008). Regaining Impact. Nordicom Review. 29. Henta frå https://doi.org/10.1515/nor2017-0187

Erstad, O., Gilje, Ø. \& de Lange, T. (2007). Re-mixing multimodal resources: multiliteracies and digital production in Norwegian media education. Learning, Media and Technology, 32(2), 183-198. https://doi. org/10.1080/17439880701343394

Erstad, O., Gilje, Ø., Sefton-Green, J. \& Vasbø, K. (2009). Exploring 'learning lives': community, identity, literacy and meaning. Literacy, 43(2). https://doi.org/10.1111/j.1741-4369.2009.00518.x

Evensen, L. S. (2013). Utvikling eller innvikling? Tidlig skriving før barn møter skolen. I M. Semundseth \& M. H. Hopperstad (Red.), Barn lager tekster. Om barns tidlige tekstproduksjon og de voksnes betydning (s. 47-59). Oslo: Cappelen Damm Akademisk.

Fast, C. (2007). Sju barn lär sig läsa och skriva. Familjeliv och populärkultur $i$ möte med förskola och skola (Doktoravhandling, Uppsala universitet). Henta frå https://www.diva-portal.org/smash/get/diva2:169656/ fulltext01.pdf

Forsman, M. (2017). Duckface/Stoneface. Selfie stereotypes and selfie literacy in gendered media practices in Sweden. I D. Lemish \& M. Götz (Red.), Beyond stereotypes. Images og boys and girls, and their consequences (s. 193-202). Gøteborg: Nordicom.

Gilje, Ø. (2007). Mediefagets produksjonsprosesser - morgendagens kompetanse? Nordic fournal of Digital Literacy, 2(4), 226-243. Henta frå https://www.idunn.no/dk/2007/04/mediefagets_produksjonsprosesser_-_ morgendagens_kompetanse

Gilje, Ø. (2010). Mode, mediation nd moving images. An inquiry of digital editing practices in media education (Doktoravhandling). Universitetet i Oslo, Oslo.

Gjems, L. (2016). Barnehagens arbeid med tidlig litterasitet - på barns vilkår. Bergen: Fagbokforlaget. 


\section{Forsking på barn og ungdoms tekstar og tekstpraksisar på fritida, med eit nordisk fokus}

Gough, D., Oliver, S. \& Thomas, J. (2012). An introduction to systematic reviews. London: Sage Publications.

Heath, S. B. (1982). Protean shapes in literacy events: Ever-shifting oral and literate traditions. I D. Tannen (Red.), Spoken and written language: Exploring orality and literacy. New Jersey: Ablex Publishing Corporation.

Hennig, A. (2018). Reven får stemme: Animasjonsfilm som uttrykk for litterær kompetanse og faglighet. I M. Rogne \& L. R. Waage (Red.), Multimodalitet i skole- og fritidstekstar (s. 181-195). Bergen: Fagbokforlaget.

Hernwall, P. (2001). Barns digitala rum: berättelser om e-post, chatt $\mathcal{G}$ Internet. Henta frå urn:nbn:se:su:diva-143017

Hilmarsen, H. V. \& Arnseth, H. C. (2017). Livet på Instagram. Ungdoms digitale forlengelser av sosiale relasjoner og vennskap. Tidsskrift for ungdomsforskning, 17(1), 3-23. Henta frå https://journals.hioa.no/ index.php/ungdomsforskning/article/view/2109

Hoel, T. (2018). "Arne spiller dataspill». Literacypraksiser forut for og utenfor den formelle opplæringen. I M. Rogne \& L. R. Waage (Red.), Multimodalitet $i$ skole- og fritidstekstar. Bergen: Fagbokforlaget/LNU.

Hopperstad, M. H. (2013). En toåring maler tekst. I M. Semundseth \& M. H. Hopperstad (Red.), Barn lager tekster. Om barns tidlige tekstproduksjon og skriving i barnehage og hjem (s. 29-46). Oslo: Cappelen Damm Akademisk.

Hopperstad, M. H., Lorentzen, R. T. \& Semundseth, M. (2009). Hvilke interesser synes å motivere femåringer til å skrive i barnehagen?. Tidsskriftet FoU i praksis, 3(2), 45-63. Henta frå https://www.nb-ecec.org/no/ artikler/post-2555931

Hopperstad, M. H. (2016). Tegnestund og barnekultur. I H. Jæger \& J. K. Torgersen (Red.), Barnekultur (s. 110-119). Oslo: Cappelen Damm.

Haakedal, E. (2010). Hva er en disippel? Multimodalitet i elevarbeidsbøker. I E. S. Tønnessen (Red.), Sammensatte tekster. Barns tekstpraksis. Oslo: Universitetsforlaget.

Håberg, L. I. A. (2016). Kvardagslivets didaktikk ibarnehagen. Ansvar og arbeidsfordeling. Oslo: Universitetsforlaget.

Ilomäki, L., Taalas, P. \& Lakkala, M. (2012). Learning environment and digital literacy: A mismatch or a possibility from Finnish teachers' and students' perspective. I P. P. Trifonas (Red.), Learning the virtual life: Public pedagogy in a digital world. New York: Routledge.

Iversen, H. M. (2009). Tekstmeldinger som norskfaglig potensial: En tekstanalytisk og didaktisk tilnærming. HumanIT, 10(2). Henta frå https://humanit.hb.se/article/view/86

Jensen, S. H. (2016). Gaming as an English language learning resource among young children in Denmark. CALICO fournal, 34, 1-19. Henta frå http://files.eric.ed.gov/fulltext/EJ1143385.pdf

Juuhl, G. K. (2017). Nynorsk i skriftkvardagen til Matias, fire og eit halvt. I E. Bjørhusdal \& I. B. Budal (Red.), Nynorsk med dei minste (s. 76-94). Oslo: Samlaget.

Juuhl, G. K. (2014). I det mykje skrivne. Ei undersøking av ungdoms digitale tekstar $i$ skule og fritid som situerte, retoriske handlingar (Doktoravhandling, Universitetet i Oslo). Henta frå https://www.duo.uio.no/ handle/10852/37794

Jæger, H. (2013). NårVetle lager bildebok ved hjelp av datamaskin: en teksthendelse i hjemmet. I M. Semundseth \& M. H. Hopperstad (Red.), Barn lager tekster: om barns tidlige tekstproduksjon og de voksnes betydning (s. 116-133). Oslo: Cappelen Damm Akademisk.

Jæger, H. (2016). Å lese medietekster på ipaden. Observasjoner av en medievant fireårings bruk av iPad i hjemmet. Tidsskrift for nordisk barnehageforskning, 12. https://doi.org/10.7577/nbf.1363

Karlsson, A. M. \& Ledin, P. (2002). Cyber, hyper och multi. Några reflektioner kring IT-ålderns textbegrepp. Human IT, 2(3). Henta frå http://etjanst.hb.se/bhs/ith/23-00/amk.htm. Lasta ned: 14.12.19.

Karrebæk, M. (2013). Fodboldkort i indskolingen: Literacy, populærkultur og polycentricitet I en minoritetsdrengs hverdagsliv. NordAnd, 9, 9-31.

Kotilainen, S. (2009). Promoting youth civic participation with media production: the case of Youth Voice Editorial Board. Comunicar, 16(32). Henta frå https:/www.revistacomunicar.com/verpdf.php?numero= 32\&articulo=32-2009-21\&idioma=en

Kotilainen, S. \& Rantala, L. (2010). Civic media education supports a public voice for youths. I S.-B. Granlund \& S. Kotilainen (Red.), Media literacy education. Nordic perspectives. Göteborg: Nordicom.

Kotilainen, S. \& Suoninen, A. (2013). Cultures of media and information literacy among the young. Southnorth viewpoints. I U. Carlsson \& S. H. Culver (Red.), Media and information literacy and intercultural dialogue. (s. 141-162). Göteborg: Nordicom.

Kunnskapsdepartementet. (2017). Rammeplan for barnehagen: Forskrift om rammeplan for barnehagens innhald og oppgåver. Henta frå https://www.udir.no/globalassets/filer/barnehage/rammeplan/rammeplan-for-barnehagennynorsk2017.pdf

Kvåle, G. (2020). Er det riktige det viktige? Literacy-syn og kvalitetstrekk i kommersielle abc-apper for norskspråklige førskolebarn. Nordic fournal of Literacy Research, 6(1), 6-25. https://doi.org/10.23865/njlr. v6.1746 


\section{G. K. Fuuhl E M. Michelsen}

Lantz-Andersson, A. (2015). Transformed framings on Facebook: Students' diverse linguistic repertoires in the contexts of practicing English as a second language. Fournal of Social Media and Inderatctive Learning Environments, 3(3), 200-218. https://doi.org/10.1504/IJSMILE.2015.072299

Lantz-Andersson, A. (2017). Language play in a second language: Social media as contexts for emerging Sociopragmatic competence. Education and Information Technologies. https://doi.org/10.1007/s10639-0179631-0

Laursen, H. P. \& Daugaard, L. M. (2012). Multilingual classrooms as negotiations of language and literacy. I A. Pietkänen-Huhta \& L. Holm (Red.), Literacy practices in transitions: perspectives from the Nordic countries (s. 103-118). Bristol: Multilingual Matters.

Leinonen, J. \& Sintonen, S. (2014). Productive participation - Children as active media producers in Kindergarten. Nordic journal of digital literacy, 3(9), 216-236. Henta frå https://www.idunn.no/dk/2014/03/ productive_participation_-_children_as_active_media_produce

Lindstrand, F. (2011). Att erkänna och urskilja: Ett designorienterat multimodalt fokus på barns meningsskapande. I J. Smidt, E. S. Tønnessen \& B. Aamotsbakken (Red.), Tekst og tegn. Lesing, skriving og multimodalitet $i$ skole og samfunn. Trondheim: Tapir Akademiske Forlag.

Lindstrand, S. H. (2015). Are we spinning or is it the board? - Young children's interaction with an interactive whiteboard in preschool. Nordic Fournal of Digital Literacy, 10(3), 114-124. Henta frå https://www.idunn. no/dk/2015/03/are_we_spinning_or_isittheboard_-_youngchildrens_inte

Lorentzen, R. T. (2002). «Til pappa og mamma fra Ingrid» - om det første barn skriv. I I. Mjør (Red.), Kulturbarnehagen (s. 93-111). Oslo: Samlaget

Lüders, M. (2007). Being in mediated spaces. An enquiry into personal media practices. (Doktoravhandling). Universitetet i Oslo, Oslo.

Malmbjer, A. (2012). Elevers skriftbruk i och utanför skolan. I S. Matre \& A. Skaftun (Red.), Skriv! Les! 1. Artikler fra den forste nordiske konferansen om skriving, lesing og literacy. Trondheim: Akademika forlag.

Marklund, L. \& Dunkels, L. (2016). Digital play as ameans to develop children's literacy and power in the Swedish preschool. Early Years, 36(3), 289-304. https://doi.org/10.1080/09575146.2016.1181608

Matre, S., Sjøhelle, D. K. \& Solheim, R. (2012). Ekspressive tekstar av unge skrivarar: om kjensleutløp, identitetsarbeid og skriveutvikling. I S. Matre, D. K. Sjøhelle \& R. Solheim (Red.), Teorier om tekst $i$ møte med skolens lese- og skrivepraksiser. Oslo: Universitetsforlaget.

Medietilsynet. (2016). Barn og medier 2016. 9-16-åringers bruk og opplevelse av medier. Oslo: Medietilsynet. Henta frå https://medietilsynet.no/globalassets/publikasjoner/barn-og-medier-undersokelser/barn-og-medier-2016komprimert-ensidig.pdf

Michelsen, M. (2016). Teksthendelser $i$ barns hverdag. En tekstetnografisk studie av åtte barns literacy og deres meningsskaping på Internett (Doktoravhandling, Universitetet i Oslo). Henta frå http://urn.nb.no/URN: NBN:no-55188

Michelsen, M. (2016). Mønsterarket som læringsobjekt. Hva lærer et barn av å fylle ut en side i en fargeleggingsbok. Norsk pedagogisk tidsskrift, 100(1), 3-14. https://doi.org/10.18261/issn.1504-2987-2016-01-02

Maagerø, E. (2005). Harry's gameboy: when children produce cartoon film. I E. Maagerø, K. L. Berge \& M. A. K. Halliday (Red.), Semiotics from the north: Nordic approaches to systemic functional linguistics (s. 153-174). Oslo: Novus forlag.

Maagerø, E. (2012). Pulverheksa og Grønnskollingen. Teksthendelser i barnehagen. I D. Skjelbred \& A. Veum (Red.), Literacy i laringskontekster. Kristiansand: Høyskoleforlaget.

Nygren, P. \& Bjørgen, A. (2010). Childrens engagement in digital practices in leisure time and school. Nordic Fournal of Digital Literacy, 5(2), 115-133. Henta frå https://www.idunn.no/dk/2010/02/art01

Nyjordet, B. (2010). Små barn på nett. I E. S. Tønnessen (Red.), Sammensatte tekster. Barns tekstpraksis. Oslo: Universitetsforlaget.

Petersen, P. (2015). «-That's how much I can do!» - Children's agency in digital tablet activities in a Swedish preschool environment. Nordic Fournal of Digital Literacy, 10(3), 145-169. Henta frå https://www.idunn.no/ dk/2015/03/_thats_how_much_i_can_do_-_childrens_agency_in_digita

Pietikäinen, S. \& Dufva, H. (2014). Heteroglossia in action: Sami children, textbooks and rap. I A. Blackledge \& A. Creese (Red.), Heteroglossia as practice and pedagogy. Dordrecht: Springer Netherlands.

Purcell-Gates, V. (1996). Stories, coupons, and the TV guide: relationships between home literacy experiences and emergent literacy knowledge. Reading Research Quarterly, 31(4), 406-428. https://doi.org/10.1598/ RRQ.31.4.4

Prøitz, T. S. (2015). Metoder for systematiske kunnskapsoversikter. Stockholm:Vetenskapsrådet. Henta frå https:// publikationer.vr.se/wp-content/uploads/2015/03/Metoder-for-systematiske-kunnskapsoversikter_web.pdf 


\section{Forsking på barn og ungdoms tekstar og tekstpraksisar på fritida, med eit nordisk fokus}

Ringdal, E. (2002). 16 år og tekstmeldar: Stadig myldrande skriving (SMS). I J. L. Tønnesson (Red.), Den flerstemmige sakprosaen. Bergen: Fagbokforlaget/LNU.

Røyneland, U. (2018). Virtually Norwegian: Negotiating language and identity on YouTube. I Multilingual youth practices in computer mediated communication (s. 3-27). Cambridge: Cambridge University Press.

Sandvik, M., Smørdal, O. \& Østerud, S. (2012). Exploring iPads in Practitioners' Repertoires for Language Learning and Literacy Practices in Kindergarten. Nordic Fournal of Digital Literacy, 3(7), 204-221. Henta frå https://www.idunn.no/dk/2012/03/exploring_ipads_in_practitioners_repertoires_for_language_

Schultz, K., Hull, G. \& Higgs, J. (2016). After writing, after school. I C. MacArthur, S. Graham \& J. Fitzgerald (Red.), Handbook of writing research (s. 102-115). New York, London: Guilford Press.

Schwebs, T. \& Otnes, H. (2006). Tekst.no. Strukturer og sjangrer i digitale medier (2. utg.). Oslo: Cappelen Akademisk Forlag.

Sefton-Green, J. (2013). Learning at not-school: A review of study, theory and advocacy for education in non-formal settings. Cambridge, MA: MIT Press.

Semundseth, M. (2006). Førskolebarns tekstproduksjon i hjemmet. Barn, 24(4), 31-44.

Silseth, K. (2012). The multivoicednesss of game play: Exploring the undfolding of a student's learning trajectory in a gaming context at school. International fournal of Computer Supported Collaborative Learning, 7(1), 63-84. https://doi.org/10.1007/s11412-011-9132-x

Skaar, H. (2010). Branded selves: How children relate to marketing on a social network site. Fournal of Children and Media, 3(3), 249-267. https://doi.org/10.1080/17482790902999926

Skaar, H. (2011). The relevance and educational value of social network sites for classroom literacy learning. Nordic Fournal of Digital Literacy, 6 (spesialnummer), 340-356. Henta frå https://www.idunn.no/dk/2011/ special_issue/art01

Smahel, D., Machackova, H., Mascheroni, G., Dedkova, L., Staksrud, E., Ólafsson, K., Livingstone, S. \& Hasebrink, U. (2020). EU Kids Online 2020: Survey results from 19 countries. EU Kids Online. https:// doi.org/10.21953/lse.47fdeqj01 ofo

Staksrud,E. (2013). Digitalmobbing. Hevm, hvor, hvordan, hvorfor-og hva kan voksne gjøre. Oslo: Kommuneforlaget.

Statens medieråd. (2020). Ungar och medier 2019. Stockholm: Statens medieråd. Henta frå https:// statensmedierad.se/download/18.126747f416d00e1ba946903a/1568041620554/Ungar\%20och\%20 medier\%202019\%20tillganglighetsanpassad.pdf

Stuedahl, D. \& Smørdal, O. (2011). Young visitors' 'messing around' in museums: exploring social media to engage teens in participation. Barn, 3(4), 169-191.

Suoninen, A. (2014). Lasten mediabarometri 2013. 0-8-vuotiaiden mediankäyttö ja sen muutokset vuodesta 2010 [Nettressurs]. Helsinki: Nuorisotutkimusverkosto/Nuorisotutkimusseura. Verkkojulkaisuja 75. Henta frå http://www.nuorisotutkimusseura.fi/julkaisuja/lastenmediabarometri2013.pdf

Svennevig, J. \& Johansen, R. (2011). Social and pragmatic variation in the sequential organization of talk. I K. Aijmer \& G. Andersen (Red.), Pragmatics of Society (Handbook of Pragmatics 5) (s. 473-500). Mouton: de Gruyter.

Svensson, T. (2014). Alexander, Sara og skriften. En skriftbruksetnografisk studie av barn $i$ mellanåren (Doktoravhandling, Örebro universitet). Henta frå urn:nbn:se:oru:diva-33834

Svoen, B. \& Gilje, Ø. (2012). Policy making and practoces of production across contexts of learning. Nordic Fournal of Digital Literacy, 7(4), 284-301. Henta frå https:/www.idunn.no/dk/2012/04/policy_making_ and_practices_of_production_across_contexts_o

Sørensen, B. H. (2001). Chat - identitet, krop og kultur. I B. H. Sørensen (Red.), Chat: Leg, identitet, socialitet og laring (s. 15-36). København: Gads.

Sørensen, B. H. (2005). Information and computing technology and the gap between school pedagogy and children's culture. Pedagogy, Culture and Society, 13(1), 43-58. https://doi.org/10.1080/14681360500200214

Sørensen, B. H., Danielsen, O. \& Nielsen, J. (2007). Children's informal learning in the context of schools of the knowledge society. Education Information Technology, 12, 17-27. Henta frå https://vbn.aau.dk/en/ publications/childrens-informal-learning-in-the-context-of-school-of-knowledge

Talaas, P., Tarnanen, M., Kauppinen, M. \& Pöyhönen, S. (2008). Media landscapes in school and in free time two parallel realities? Computer Science, 2008.

Tolchinsky, L. (2004). Childhood conceptions of literacy. I T. Nunes \& P. Bryant (Red.), Handbook of children's literacy (s. 11-29). Dordrecht Springer.

Tønnessen, E. S. (2007). Generasjon.com. Mediekultur blant barn og unge. Oslo: Universitetsforlaget.

Tønnessen, E. S. \& Hoel, T. (2019). Designing dialogs around picture book apps. Reading in the digital age: Young children's experiences with E-books. Springer, 10, 197-215. 


\section{G. K. Fuuhl E M. Michelsen}

Undrum, L. V. M. \& Veum, A. (2018). Kritisk literacy i den digitale tekstkulturen. Unges selvfremstilling i og selvrefleksjon over kommunikasjon i sosiale medier. I K. Kverndokken (Red.), 101 litteraturdidaktiske grep - om å arbeide med skjønnlitteratur og sakprosa. Bergen: Fagbokforlaget/LNU.

Veum, A. (2013). Blogging på rosa skjerm. Om roller og relasjonar i ungjentebloggar. I S. Hållsten, H. S. Rehnberg \& D. Wojan (Red.), Text, kontext och betydelse. Sex nordiska studier i systemisk-funktionell lingvistik. Stockholm: Södertörns Högskola.

Wahlström, M. \& Törnberg, A. (2019). Social media mechanisms for right-wing political violence in the $21^{\text {st }}$ century: Discursive opportunities, group dynamics, and co-ordination. Terrorism and PoliticalViolence, 1-22. https://doi.org/10.1080/09546553.2019.1586676

Wedin, Å. (2012). Literacy in negotiating, constructing and manifesting identities: the case of migrant unaccompanied asylum-seeking children in Sweden. I A. Pitkänen-Huhta \& L. Holm (Red.), Literacy practices in transition: Perspectives from the Nordic countries. Bristol: Multilingual Matters.

Wernholm, M. (2018). Children's shared experiences of participating in digital communities. Nordic fournal of Digital Literacy, 13(4), 38-55. https://doi.org/10.18261/issn.1891-943x-2018-04-04

Wernholm, M. \& Reneland-Forsman, L. (2019). Children's representations of self in social media communities. Learning, Culture and Social Interaction, 23, 1-15. Henta frå urn:nbn:se:Inu:diva-88898

Åberg, E. S. (2018). Children's collaborative technology-mediated storymaking: Instructional challenges in early childhood education (Doktoravhandling, Göteborgs universitet). Henta frå http://hdl.handle.net/2077/49958

Åberg, E. S., Lantz-Andersson, A. \& Pramling, N. (2015). Children's digital storymaking. The negotiated nature of instructional literacy events. Nordic fournal of Digital Literacy, 10(3), 170-189. Henta frå https:// www.idunn.no/dk/2015/03/childrens_digital_storymaking_-_the_negotiated_nature_of_i 